\title{
Fighting Food Allergy by Inducing Oral Tolerance: Facts and Fiction
}

\author{
Xiaotong Yang ${ }^{a}$ Rui Liang ${ }^{a}$ Qianlu Xing ${ }^{b}$ Xiaojuan $\mathrm{Ma}^{\mathrm{a}}$ \\ aSchool of Public Health, Zunyi Medical University, Zunyi, China; ${ }^{\mathrm{b}}$ Department of Pediatrics, The Second Affiliated \\ Hospital of Zunyi Medical University, Zunyi, China
}

\section{Keywords}

Oral tolerance $\cdot$ Intestinal immune system · Processing methods

\begin{abstract}
The prevalence of food allergy (FA) is increasing, and there is an urgent need to take effective measures against it. One important measure is the avoidance diet, which shows a disadvantage, especially in case of accidental exposure. Oral tolerance restoration sheds new light on the control of FA. Oral tolerance is naturally a state of systemic unresponsiveness of the gastrointestinal tract to food antigens and its restoration can be a clinical therapy for FA. Its immune basis lies on the intestinal mucosal immune system and factors, such as gut microbiota and food processing methods, are also important. This review presents recent advances in oral tolerance and its closely related factors.

๑) 2021 S. Karger AG, Basel
\end{abstract}

\section{Introduction}

Food allergy (FA) is an adverse reaction to certain foods or food additives that are harmless to unsusceptible individuals. The response can be immunoglobulin $\mathrm{E}$ (IgE)-mediated (type I hypersensitivity) or non-IgE-mediated (type IV hypersensitivity), and the former is the most common type. Allergic reactions often occur in the skin, digestive system, or respiratory system, and there can be systematic and even life-threatening symptoms [1]. Oral food challenge results, which were published in the recent 5 years presented that, in developed countries, $3.8-11 \%$ of children had FA [2-4]; however, for adults, the prevalence was from 0.2 to $4.1 \%[5,6]$. The occurrence of FA in developing countries is comparatively lower, with about $0.5-2.5 \%$ prevalence among children $[7,8]$. To make it worse, the incidence of FA seems to be increasing over the past 20 years $[9,10]$. On the other hand, epidemiological data showed that the types of food allergens responsible for eliciting FA vary among different continents. In Europe, United Kingdom, Australia, Canada, and the USA, peanuts are one of the main causes of FA [11-15]. While peanut allergy is not so common in many countries in Asia [16, 17], milk and eggs are the common allergenic foods among infants and young children of all countries [11, 18-20].

Till date, there are no well-accepted measures for the treatment of FA, and specific food elimination diet is the recommended choice. However, strict food avoidance can lead to poor adherence or malnutrition, and the risk of serious allergic reactions may increase when certain allergenic foods are accidentally ingested after a long-term

Edited by: H.-U. Simon, Bern. karger@karger.com www.karger.com/iaa
(C) 2021 S. Karger AG, Basel

Karger!
Correspondence to:

Xiaojuan Ma, martha_ok2010@hotmail.com 
avoidance. Thus, effective therapies against FA are urgently needed. So far, oral immunotherapy proposed in clinical and related experimental studies has become a potential preventive agent and an effective method against some FA. The ultimate goal of oral immunotherapy is to induce clinical tolerance, a state of restored permanent oral tolerance that is defined as no allergic response during oral food challenge after withdrawal of the antigen therapy, so that elimination diet can be stopped [21].

FA is fundamentally a state of loss of oral tolerance to food. After certain allergenic protein ingestion, it confronts denaturation and degradation in the digestive tract. However, a small fraction of the intact molecule or part of the protein (epitope) escapes from the digest process and comes to the intestinal cavity and intestinal mucosa. Then, it crosses the epithelial barrier through various mechanisms, gets help from specific types of epithelial cells, such as antigen-sampling microfold cells and goblet cells, and is then transferred to dendritic cells (DCs) for presentation [22]. Antigen presentation is the basis for FA. Gut microbiome and T cell also play important roles in oral tolerance/FA induction and maintenance. In addition, food processing methods may affect how allergenic proteins are digested or transferred, thus making certain food edible for allergic individuals. Moreover, the immune-modulatory effect of processed foods has also been reported. This review focuses on oral tolerance and its related factors, including intestinal mucosal immune defense, intestinal microbiome, and food processing methods.

\section{Oral Tolerance}

In 1911, Wells and Osborne [23] demonstrated that guinea pigs did not develop an allergic reaction to corn or oat protein, which are part of their diet. The state of immunological unresponsiveness to food antigens ingested is called oral tolerance [24]. It is different from the immune deficiency or the inhibition state caused by receiving an immunosuppressive agent since responses are still triggered by other antigens. One of the key events for the break of oral tolerance to food sensitization is Treg reprogramming to Th2, and higher IgE level promotes Th2 cell induction and further inhibits Treg [25, 26]. Evidence also suggests that IgG4, in relation to IgE, is more accurate in terms of FA diagnosis when compared with specific IgE alone [27]. In recent years, FA research focused on infants and young children in early oral tolerance induction since "allergen avoidance strategy" is obviously not suitable for the control of allergic reactions [28]. For instance, by adding or avoiding peanut extract in 640 targeting infants until 5 years old, Du Toit et al. [29] reported that early consumption of peanut can significantly reduce the frequency of peanut allergy from occurrence of $13.7 \%$ in the exclusion group to $1.9 \%$ in the consumption group. Moreover, the peanut consumption group had higher ratios of peanut-specific IgG4/IgE, which indicates an immune-modulatory effect.

For many patients who were already allergic to certain foods, restoration of specific oral tolerance was proven to be a good treatment. For certain types of FA, such as milk and egg allergy, most of the cases present allergic reactions before 1 year of age and the majority of them outgrow FA before school age. However, for some other types, such as peanut and treenut allergy, it is more difficult to restore oral tolerance. A more detailed description for natural history of FA in different food types has recently been reviewed [30]. Immunological changes in restored oral tolerance involve an increase in specific IgG4 and Treg levels, as well as a reduced Th2 response [31-33]. Clinically, its basic strategy is to reduce adverse reactions to allergic food proteins by repeated exposure to gradually increasing doses. Fifty milk allergy subjects (median 10.3 years) participated in a 3-stage oral tolerance restoration test. The whole procedure lasted for 67 days, beginning with one drop of $1 \%$ milk solution, and ending with $250 \mathrm{~mL}$ of milk. Results showed that $23 \mathrm{pa}-$ tients achieved full tolerance, 9 patients achieved partial tolerance, and 18 patients failed to achieve tolerance. The achieved clinical tolerance lasted for at least 5 years [34]. In an egg tolerance restoration test, 20 patients (5-11 years) were randomly divided into treatment and control groups. The treatment group followed a dosage increase protocol, starting with 1 drop of raw hen egg and ending at 176 days with $40 \mathrm{~mL}$ of raw hen egg (a dose equivalent to a small egg). After 6 months, $9 / 10$ children in the treatment group achieved partial tolerance and 1 child was not tolerant. No oral tolerance was achieved in the control group [35]. Although specific oral tolerance restoration was effective in many clinical trials, long-term efficacy to sustain the achieved tolerance and uniformed protocol is still on the way [36].

\section{Intestinal Mucosal Immune Basis for Oral Tolerance}

Sensitivity to food allergens begins with the absorption of antigens by the gut and the main route of exposure to food ingredients is through the gastrointestinal 
Fig. 1. Intestinal mucosal immune system and its role in processing food allergens. Antigens can be transported across the intestinal epithelial cells with the help of microfold cells and goblet cells, or by mononuclear phagocytes grasping antigens through the tight junctions between enterocytes (in cases of inflammation). Then, the antigen processing cells process the antigens and present them to $\mathrm{T}$ cells to initiate the immune defense. Isolated lymphoid follicles, MLN, and Peyer's patches are the places where antigens activate naive and memory T lymphocytes. MLN, mesenteric lymph nodes; PP, Peyer's patch; LP, lamina propria; DC, dendritic cell.

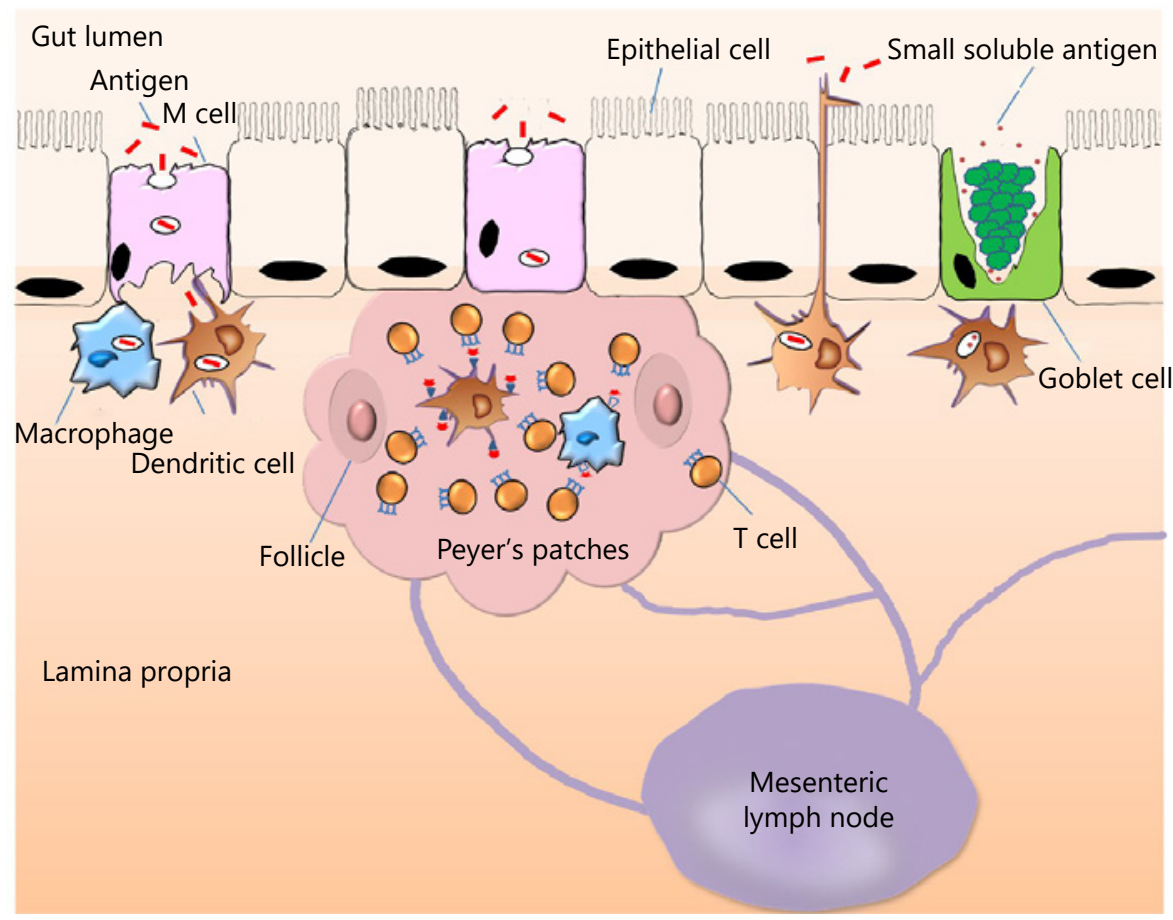

mucosal surface. Gastrointestinal mucosa is the largest immune area in the human body, which distinguishes between beneficial and harmful components in the intestinal tract, so as to maintain systemic immune tolerance. Physically, the components of the intestinal mucosal immune defense can be divided into 3 different parts: intestinal epithelial barrier, lamina propria (LP), and gut-associated lymphoid tissue. Functionally, the intestinal mucosal immune defense system can be divided into induction sites and effector sites. The induction sites, which comprise isolated lymphoid follicles, mesenteric lymph nodes (MLN), and Peyer's patches (PPs), are the places where antigens activate naive and memory $\mathrm{B}$ and $\mathrm{T}$ lymphocytes. The effector site where effector cells perform their action is composed of epithelial cells and LP [37]. According to the information (amount, size, shape, etc.) on the antigen entering the body, different parts of the mucosal tissue can be involved in oral tolerance induction. Among them, the vellus LP and MLN are the common induction sites of oral tolerance, and PPs may play a subordinate role [38]. The intestinal mucosal immune system and its role in processing food allergens are shown in Figure 1.

The initial structure of PPs (Anlagen) in human, which contains aggregates of Tlymphocyte and some B lymphocyte, can be distinguished in 14-week-old fetuses [39].
Later and before puberty, the number and size of PPs increase with age. Dysplasia of MLN or PPs is consistent with reduced sIgA and oral tolerance, thereby increasing susceptibility to infection and FA [40]. Besides, oral tolerance failed to be induced in both MLN- and PPs-deficient mice [41]. Intestinal epithelial cell also contributes to the maintenance of oral tolerance [42]. Lymphocytes called intraepithelial lymphocytes, which are scattered among epithelial cells, make contact with intestinal antigens directly and functions as immune defense front against invading pathogens [43]. Together, these cells form an immune barrier in the intestinal tract, which is essential for a balanced intestinal mucosal immune system [44]. Without their matching, the intestinal immune system selfdestructs, causing inability to induce protective immunity and/or tolerance, thus further leading to diseases, such as FA $[45,46]$.

DCs, which are partly located throughout the gut, are vital for T-cell activation and antigen presentation to $\mathrm{B}$ cell, and the mechanism of oral tolerance is related to the recognition of food antigens by DCs $[47,48]$. Moreover, antigen-specific immunotherapy was found to induce tolerogenic DC in patients with FA [49]. Intestinal DCs contain both $\mathrm{CD}_{103^{+}}$and $\mathrm{CD} 103^{-}$subsets. In LP, both $\mathrm{CX} 3 \mathrm{CR} 1^{+}$macrophages and $\mathrm{CD} 103^{+} \mathrm{DCs}$ are necessary for mucosal immunity. Generally, the abundant CX- 
$3 \mathrm{CR}^{+}$macrophages are long-lived phagocytic cells, which do not normally migrate to MLN and have a weaker effect on antigen presentation to $\mathrm{T}$ cells. In contrast, intestinal $\mathrm{CD} 103^{+} \mathrm{DCs}$ are short-lived cell and can migrate to MLN, present antigen to T cells more powerfully, and induce oral tolerance under noninflammatory conditions [50]. CD $103^{+}$DCs from gut-associated lymphoid tissue were found to express IgA and modulate B-cell migration in a $\mathrm{T}$ cell-independent manner, thus shaping mucosal immunity [51]. Moreover, they can also initiate T cell by expressing high levels of factors, such as TGF- $\beta$ and RALDH2 enzymes, and were found to contribute to the development of intestinal homing Treg cells [52]. On the other hand, $\mathrm{CD}_{103}{ }^{-} \mathrm{DCs}$ were found to induce the development of both IFN- $\gamma$ and IL-17-producing effector T cells [53].

\section{T Cell and Oral Tolerance}

According to different CD molecular phenotypes, initial $\mathrm{T}$ cells can be divided into $\mathrm{CD} 3^{+} \mathrm{CD} 4^{+} \mathrm{CD} 8^{-} \mathrm{T}$ cells $\left(\mathrm{CD} 4^{+} \mathrm{T}\right.$ cell $)$ and $\mathrm{CD}^{+}{ }^{+} \mathrm{CD} 4^{-} \mathrm{CD} 8^{+} \mathrm{T}\left(\mathrm{CD} 8^{+} \mathrm{T}\right.$ cell $)$ cells. When stimulated by a specific antigen after presentation, the initial $\mathrm{CD} 4^{+} \mathrm{T}$ cells can differentiate into cells, such as Th1, Th2, Th17, or Treg, which are important for FA [54]. It has long been accepted that pathogenic mechanisms of FA involve the skew of antigen-specific T-cell responses to Th2 [55-57]. Injection of $\mathrm{mAb}$ to pro-Th2 cytokines IL-25, IL-33, or thymic stromal lymphopoietin was found to strongly inhibit FA development in Balb/c mice model. Moreover, injection of 3-mAb cocktail in the immunization process induced egg white tolerance [58]. Th2 to Th1 response shift and increase in Treg were found to be associated with long-term tolerance in clinical trials [59].

Many studies have shown that Tregs play an important role in FA and maintenance of tolerance. Treg cells can suppress induction and effector stages of FA through various mechanisms, such as Th2 cells, IgE, and effector cells degranulation inhibition, and Tregs induced in periphery after antigenic stimulation can be divided into 3 groups: Foxp $3^{+}$Treg cells, TGF-expressing Th3 cells, and CD4 ${ }^{+}$Foxp3-IL-10-producing Treg (Tr1) cells [60]. By treating FA mice models with a low dose of IL-2, Foxp $3^{+}$Treg increase and activation were found to reduce clinical manifestations of FA. In Treg-depleted mice, no such effect was proven, thus indicating the central role of Treg in FA inhibition caused by low dose of IL-2 [61]. Kim et al. [62] demonstrated the immunosuppressive ef- fect of Foxp $3^{+}$Treg through common diet, which helps to establish oral tolerance. Although research in this field mainly involved animal experiments, clinically, there is also evidence that patients with restored oral tolerance have higher Foxp $3^{+}$Treg level when compared with those with FA $[63,64]$. Since a recent review [65] addressed Foxp $3^{+}$Treg and oral tolerance in detail, we will not unfold the scroll here.

Th3 cell is a different type of peripheral regulatory $\mathrm{CD} 4^{+} \mathrm{T}$ cells, which primarily secretes TGF- $\beta$, an important mediator for oral tolerance induction [66]. In 30 children with multiple FA, dominant mucosal abnormality was found not to be skewed to Th2, but impaired the generation of Th3 cells, indicating the importance of Th3 in FA [67]. When fed a TGF- $\beta$-enriched formula to mice with ovalbumin (OVA)-induced $\mathrm{FA}$, allergenic responses were decreased when compared with the control group. IgE, IgG1, mMCP-1, and correlated cytokine levels all indicated decreased allergic responses [68]. Carrier et al. [69] found that Th3 cells can act directly and induce Foxp $3^{+}$to act indirectly as the central mediator of peripheral immune tolerance using a transgenic mouse model of TGF-mice. There are evidences that TGF-enriched formula helps infants to build oral tolerance [70]. However, although many reports found a relationship between TGF- $\beta$, FA, and oral tolerance, the clinical conclusion is still controversial [71].

In 1997, Groux et al. [72] first described $\operatorname{Tr} 1$, a regulatory $\mathrm{T}$ cell that can induce autocrine IL-10 and suppress $\mathrm{CD} 4^{+} \mathrm{T}$-cell proliferation in response to antigen. In addition to its effect on $\mathrm{CD} 4^{+} \mathrm{T}$ cells, IL-10 also promotes antigen-presenting cells to induce the production of inhibitory T cells. Tsuji et al. [73] found that IL-10 secreted by $\operatorname{Tr} 1$ could induce tolerance to low levels of beta-globulin in mice. Bergerson et al. [74] isolated peripheral mononuclear cells from pediatric patients and found that children with FA have lower $\operatorname{Tr} 1$ levels when compared with those not allergic. Knol et al. [75] studied the T-cell clones from peripheral blood of children with persistent milk allergy, outgrown milk allergy, and without allergy. Results showed a Th2 skewed response in samples from persistent milk allergy subjects, while the milk-tolerant group presented higher levels of IL-10, indicating that the cytokine might contribute to FA tolerance induction. IL-10 agonists were found to have an immune regulatory effect on cancer patients [76], but whether this therapy can be used for FA patients with food-induced anaphylaxis is yet to be determined. The role of T-cells in induction of oral tolerance is shown in Figure 2. 
Fig. 2. Role of T-cells in induction of oral tolerance.

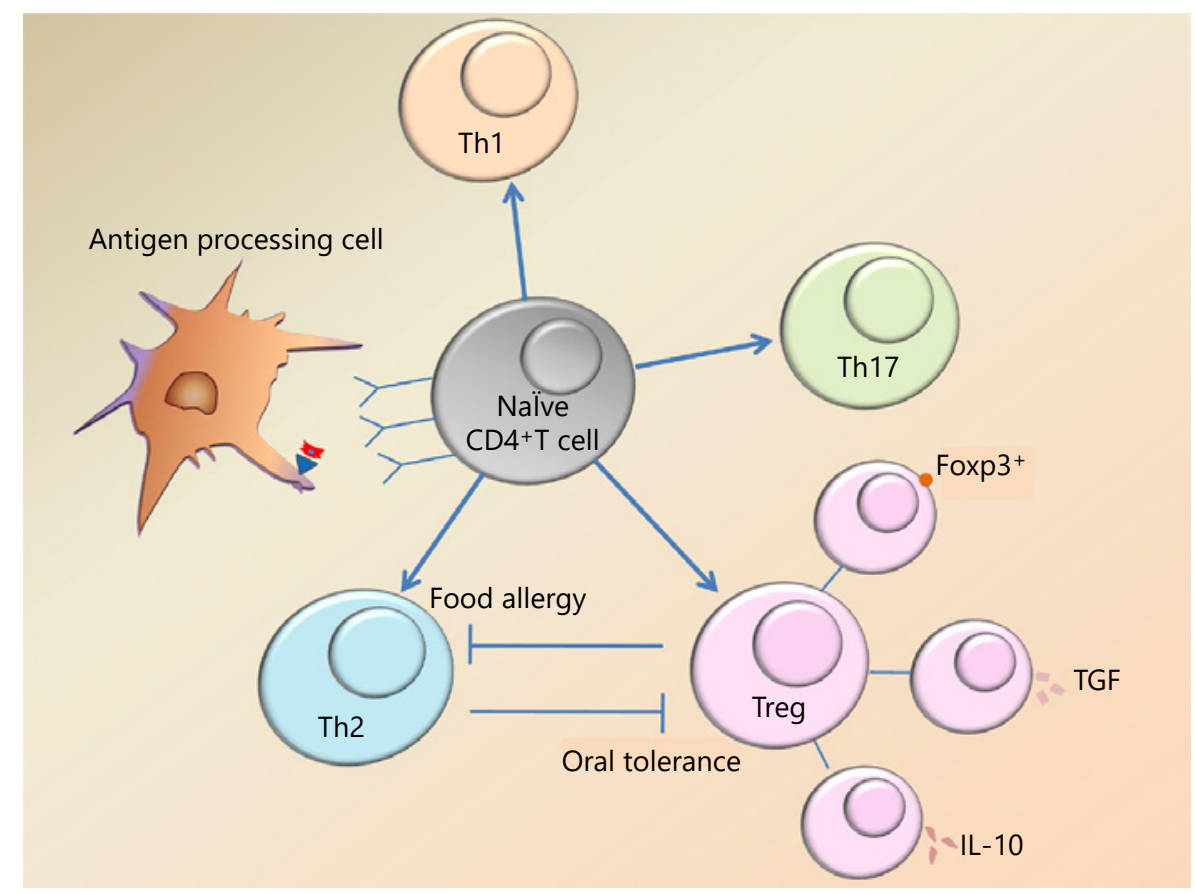

\section{Gut Microbiota and Oral Tolerance}

The intestine is exposed to microbes as early as the fetus passes through the birth canal during delivery, and it may contain as many as 100 trillion microbes by adulthood. The gut, like other tissues, is constantly attacked by various antigens. Antigens come from the outside as well as the body itself. Recent data have shown that intestinal flora plays an important role in host immune development and function [77-79]. The increased prevalence of FA over the past few decades has increased concerns about the intestinal microbiota associated with allergies and oral tolerance promotion. In fact, epidemiological studies have demonstrated that intestinal microbiota plays an important role in early induction and maintenance of tolerance; moreover, altered microbial exposure and early life colonization were found to alter the risk of FA [80-82]. The effect of microbiota in allergy and oral tolerance was further confirmed with sterile mice. Rodriguez et al. [83] reported that, compared with normal mice, sterile mice are more likely to have allergic reactions after oral administration of whey proteins. When micobiota are transplanted from healthy infants (faecal microbiota dominated by Bifidobacterium and Bacteroides species), a protective impact of FA and increased expression of Foxp3 gene in the ileum was shown, indicating that the gut microbiota is closely associated with FA and oral tolerance [84].
For infants and young children, postnatal breastfeeding is particularly important in view of early induction of oral tolerance. Breastfeeding can transfer microorganisms to infants and affect the composition of intestinal microbiota of children, since breast milk is a source of nutrients for symbiotic microorganisms, such as bifidobacteria, lactobacillus, staphylococcus, and enterococcus [85]. In a 12-month longitudinal study, breastfed infants were found to receive $27.7 \%$ of breast milk bacteria and $10.3 \%$ of areola skin bacteria in the first month of life [86]. The latest Canadian longitudinal development of healthy infants prospective study found that both increase in richness of intestinal microbiota and low Enterobacteriaceae/Bacteroidaceae ratio at 3 months of age could reduce the risk of food sensitization at 1 year old, which is related to breastfeeding [87]. Even after the introduction of solid foods, changes in bacterial diversity and composition were reported to be dose-dependently related with daily breast milk intake [86].

In addition to breastfeeding, timing to introduce solid foods that contain food allergen was also proven to affect oral tolerance induction. Many observational studies published in recent years support the idea that solid food introduction before 6 months of age could lower the risk of allergy to certain foods [88, 89]. A possible explanation might be the age-dependent relationship between infant gut microbiome and allergy. This was supported by Azad 
Table 1. Reported food processing measures that help patients tolerate processed foods in clinical trials $[94,97,98,100,102,105,106$, 117-131]

\begin{tabular}{|c|c|c|c|c|}
\hline Food & Cooking method & Rate of tolerance, $\%(n / N)$ & Age of population & Reference \\
\hline \multirow[t]{12}{*}{ Egg } & Sponge cooked at $177^{\circ} \mathrm{C}$ for $30 \mathrm{~min}$ & $63(59 / 94)$ & $\begin{array}{l}0.5-18 \text { years old, } \\
\text { median } 4.25 \text { years }\end{array}$ & Saifi et al. [97] \\
\hline & $\begin{array}{l}\text { Oral food challenge in steps: (1) ciambellone with egg; (2) frittata } \\
\text { (fried for } 3 \mathrm{~min} \text { and then baked at } 180^{\circ} \mathrm{C} \text { for at least } 30 \mathrm{~min} \text { ); (3) egg } \\
\text { boiled for } 10 \mathrm{~min} \text { (containing } 6 \mathrm{~g} \text { of egg protein) }\end{array}$ & $\begin{array}{l}88(44 / 50) \text { tolerated ciambellone, } \\
74(31 / 42) \text { tolerated frittata, and } \\
56(28 / 50) \text { tolerated boiled egg }\end{array}$ & $\begin{array}{l}0.5-16 \text { years old, } \\
\text { median } 1.78 \text { years }\end{array}$ & $\begin{array}{l}\text { Miceli Soap et al. } \\
{[98]}\end{array}$ \\
\hline & $\begin{array}{l}\text { Muffin baked at } 176^{\circ} \mathrm{C} \text { for } 30 \mathrm{~min} \text {, or waffle at } 260^{\circ} \mathrm{C} \text { for } 3 \mathrm{~min} \\
\text { (containing } 2.2 \mathrm{~g} \text { of egg protein) }\end{array}$ & $55(64 / 117)$ & $\begin{array}{l}1.6-18.6 \text { years old, } \\
\text { median } 6.9 \text { years }\end{array}$ & $\begin{array}{l}\text { Lemon-Mulé } \\
\text { et al. [102] }\end{array}$ \\
\hline & Cake (how much egg protein it contained not mentioned) & $73(/ 44 / 60)$ & Children $>5$ years old & $\begin{array}{l}\text { Des Roches et al. } \\
\text { [117] }\end{array}$ \\
\hline & $\begin{array}{l}\text { Pasteurized liquid egg proceeded in the following steps: (1) stir- } \\
\text { heated at } 65^{\circ} \mathrm{C} \text { for } 10 \mathrm{~min},(2) \text { hydrolyzed with Protamex at } 55^{\circ} \mathrm{C} \text { for } \\
2 \mathrm{~h},(3) \text { stir-heated at } 75^{\circ} \mathrm{C} \text { for } 10 \mathrm{~min},(4) \text { hydrolyzed with } \\
\text { Flavourzyme at } 55^{\circ} \mathrm{C} \text { for } 2 \mathrm{~h} \text {, and (5) stir-heated at } 90^{\circ} \mathrm{C} \text { for } 30 \mathrm{~min} \\
\text { (containing } 2.96 \mathrm{~g} \text { of egg protein) }\end{array}$ & $92(22 / 24)$ & $0.2-37.1$ years old & $\begin{array}{l}\text { Ballmer-Weber } \\
\text { et al. [118] }\end{array}$ \\
\hline & $\begin{array}{l}\text { Muffin baked at } 176^{\circ} \mathrm{C} \text { for } 30 \mathrm{~min} \text {, or waffle at } 260^{\circ} \mathrm{C} \text { for } 3 \mathrm{~min} \\
\text { (containing } 2.2 \mathrm{~g} \text { of egg protein) }\end{array}$ & $71(56 / 79)$ & $\begin{array}{l}1.6-15.8 \text { years old, } \\
\text { median } 5.8 \text { years }\end{array}$ & $\begin{array}{l}\text { Leonard et al. } \\
{[100]}\end{array}$ \\
\hline & $\begin{array}{l}\text { Muffin or cupcake baked at } 176^{\circ} \mathrm{C} \text { for } 30 \mathrm{~min} \text { (containing } 2.2 \mathrm{~g} \text { of } \\
\text { egg protein) }\end{array}$ & $84(142 / 169)$ & $\begin{array}{l}1.48-17.07 \text { years old, } \\
\text { median } 6.18 \text { years }\end{array}$ & $\begin{array}{l}\text { Bartnikas et al. } \\
\text { [119] }\end{array}$ \\
\hline & $\begin{array}{l}\text { Muffin baked at } 180^{\circ} \mathrm{C} \text { for } 20 \mathrm{~min} \text { (containing about } 1 \mathrm{~g} \text { of egg } \\
\text { protein) }\end{array}$ & $64(150 / 236)$ & $\begin{array}{l}2.1-6.8 \text { years old, } \\
\text { median } 4.5 \text { years }\end{array}$ & $\begin{array}{l}\text { Turner et al. } \\
{[120]}\end{array}$ \\
\hline & $\begin{array}{l}\text { Thirty-one of } 34 \text { patients were challenged with a boxed cake baked at } \\
176^{\circ} \mathrm{C} \text { for at least } 30 \mathrm{~min} \text { (containing } 19 \mathrm{~g} \text { of egg protein). The other } \\
3 \text { patients ingested baked cookies, donuts, or bread }\end{array}$ & $82(28 / 34)$ & $\begin{array}{l}1.2-13.8 \text { years old, } \\
\text { median } 5.9 \text { years }\end{array}$ & $\begin{array}{l}\text { Buelow et al. } \\
{[121]}\end{array}$ \\
\hline & $\begin{array}{l}\text { Muffins or cupcakes baked at } 191^{\circ} \mathrm{C} \text { for at least } 30 \mathrm{~min} \text { (containing } \\
2.2 \mathrm{~g} \text { of egg protein) }\end{array}$ & $83(43 / 52)$ & $\begin{array}{l}2.2-18.0 \text { years old, } \\
\text { median } 7.2 \text { years }\end{array}$ & Cortot et al. [122] \\
\hline & $\begin{array}{l}\text { Muffins baked at } 191^{\circ} \mathrm{C} \text { for at least } 30 \mathrm{~min} \text { (containing } 2.2 \mathrm{~g} \text { of egg } \\
\text { protein) }\end{array}$ & $66(66 / 100)$ & $\begin{array}{l}1.2-19.8 \text { years old, } \\
\text { median } 5.9 \text { years }\end{array}$ & $\begin{array}{l}\text { Lieberman et al. } \\
{[123]}\end{array}$ \\
\hline & $\begin{array}{l}\text { Muffin, omelet, hard-boiled egg, soft-boiled egg, or egg cooked by } \\
\text { other techniques chosen by parents (containing } 3.3 \mathrm{~g} \text { of egg protein } \\
\text { or more) }\end{array}$ & $77(47 / 61)$ & $\begin{array}{l}13-40 \text { months, median } \\
19.4 \text { months }\end{array}$ & $\begin{array}{l}\text { Miceli Sopo et al. } \\
{[124]}\end{array}$ \\
\hline \multirow[t]{8}{*}{ Milk } & $\begin{array}{l}\text { Baked milk challenge with cupcake baked at } 176^{\circ} \mathrm{C} \text { for } 30 \mathrm{~min} \\
\text { (containing } 1.3 \mathrm{~g} \text { of milk protein) }\end{array}$ & $76(37 / 49)$ & $\begin{array}{l}1.4-4 \text { years old, } \\
\text { median } 2 \text { years }\end{array}$ & $\begin{array}{l}\text { Sirin Kose et al. } \\
{[125]}\end{array}$ \\
\hline & Muffin baked at $176^{\circ} \mathrm{C}$ for $30 \mathrm{~min}$ (containing $2.8 \mathrm{~g}$ of milk protein) & $50(11 / 22)$ & $\begin{array}{l}4.8-13.9 \text { years old, } \\
\text { median } 8.4 \text { years }\end{array}$ & $\begin{array}{l}\text { Barbosa et al. } \\
{[106]}\end{array}$ \\
\hline & Muffin baked at $176^{\circ} \mathrm{C}$ for $30 \mathrm{~min}$ (containing $1.3 \mathrm{~g}$ of milk protein) & $74(65 / 88)$ & $\begin{array}{l}0.7-6.3 \text { years old, } \\
\text { median } 3.1 \text { years }\end{array}$ & $\begin{array}{l}\text { Kim et al. [126] } \\
\text { [97] }\end{array}$ \\
\hline & $\begin{array}{l}\text { Muffin or cupcake baked at } 176^{\circ} \mathrm{C} \text { for } 30 \mathrm{~min} \text { (containing } 1.3 \mathrm{~g} \text { of } \\
\text { milk protein) }\end{array}$ & $83(29 / 35)$ & $\begin{array}{l}3.1-18.1 \text { years old, } \\
\text { median } 8.1 \text { years }\end{array}$ & $\begin{array}{l}\text { Bartnikas et al. } \\
\text { [127] }\end{array}$ \\
\hline & Muffin baked at $180^{\circ} \mathrm{C}$ for $20 \mathrm{~min}$ (containing $0.5 \mathrm{~g}$ of milk protein) & $73(51 / 70)$ & $\begin{array}{l}2.5-9.6 \text { year old, } \\
\text { median } 5.3 \text { years }\end{array}$ & Mehr et al. [128] \\
\hline & Shortbread cookie containing $168.6 \mathrm{mg}$ of milk protein & $67.2(43 / 64)$ & $\begin{array}{l}2-16 \text { years old, median } \\
4.8 \text { years }\end{array}$ & $\begin{array}{l}\text { Gruzelle et al. } \\
\text { [129] }\end{array}$ \\
\hline & $\begin{array}{l}\text { Baked milk challenge with muffin baked at } 176^{\circ} \mathrm{C} \text { for } 30 \text { min } \\
\text { (containing } 1.3 \mathrm{~g} \text { of milk protein) Fermented milk challenge with } \\
\text { yogurt (containing } 8-10 \mathrm{~g} \text { of milk protein) }\end{array}$ & $\begin{array}{l}\text { For the } 32 \text { patients who reacted } \\
\text { to unheated milk during an OFC, } \\
38(12 / 32) \text { tolerant to yogurt, and } \\
91(29 / 32) \text { tolerant to muffin }\end{array}$ & $\begin{array}{l}7-24 \text { months, median } \\
14 \mathrm{~m}\end{array}$ & $\begin{array}{l}\text { Uncuoglu et al. } \\
{[105]}\end{array}$ \\
\hline & $\begin{array}{l}3 \text { g yogurt from SEK Company (Su"t Endu"strisi Kurumu, Istanbul, } \\
\text { Turkey) }\end{array}$ & $50(17 / 34)$ & Median 2 years old & $\begin{array}{l}\text { Küçükosmanoğlu } \\
\text { et al. [94] }\end{array}$ \\
\hline \multirow[t]{2}{*}{ Fish } & Canned tuna & $91(41 / 45)$ & Median 9.25 years & $\begin{array}{l}\text { Stavroulakis et al. } \\
{[130]}\end{array}$ \\
\hline & $90-180 \mathrm{~g}$ of canned tuna & $100(45 / 45)$ & $\begin{array}{l}1.3-30 \text { years old, } \\
\text { median } 6.0 \text { years }\end{array}$ & $\begin{array}{l}\text { Bernhisel- } \\
\text { Broadbent et al. } \\
{[131]}\end{array}$ \\
\hline
\end{tabular}

OFC, oral food challenge. 
et al. [87], who found that intestinal microbial richness at 3 months of age was associated with an increase in food sensitization at 1 year old; however, this was not true at age of 12 months. In fact, infant feeding guidelines for early food introduction, such as peanut has made corresponding changes [90]. The National Institutes of Allergy and Infectious Diseases recommends that children having severe eczema, egg allergy, or both should introduce peanut into their diet as early as 4-6 months of age under instructions from trained allergy specialists [91]. However, there is some new evidence that the introduction of supplemental foods should be after 6 months old, since the intestinal mucosal barrier in infants is immature, and that the introduction of early solid foods may cause the promotion of allergy rather than tolerance [92]. Whether solid food introduction should be performed before 6 months of age depends on factors, such as food type and nationality, and more research support is needed to draw a conclusion.

\section{Processing Method and Oral Tolerance}

Many allergenic foods were found to present reduced sensitivity after processing. Reported food processing measures that help patients tolerate processed food in clinical trials are listed in Table 1. For some FA subjects, strict avoidance diet is no longer a necessity and their quality of life has improved [93-95]. Certain processing methods can even exert immune-modulatory effects and increase host tolerance to allergenic foods. The 2 allergenic foods under investigation in this field were eggs and milk, and baking was the most common processing method adopted. Today, baked milk and baked egg diets are increasingly used against milk and egg allergy beyond an elimination diet [96].

Egg allergy is one of the most common IgE-mediated FA. Studies have shown that heating can reduce their sensitization, and $55-88 \%$ of egg allergy subjects can tolerate baked egg [97-99].

Clinical trials indicated that egg allergy children, who tolerate baked egg have increased possibility to outgrow egg allergy than those intolerate it [100]. To clarify whether intake of baked egg accelerates tolerance to regular egg, an egg elimination diet was introduced to both the baked egg tolerant and intolerant children. Results showed similar tolerance rate to raw egg between the 2 groups, while the control group (egg allergy children tolerant to baked egg and kept daily ingestion) tolerated raw egg with a higher percentage, thus indicating that baked egg con-

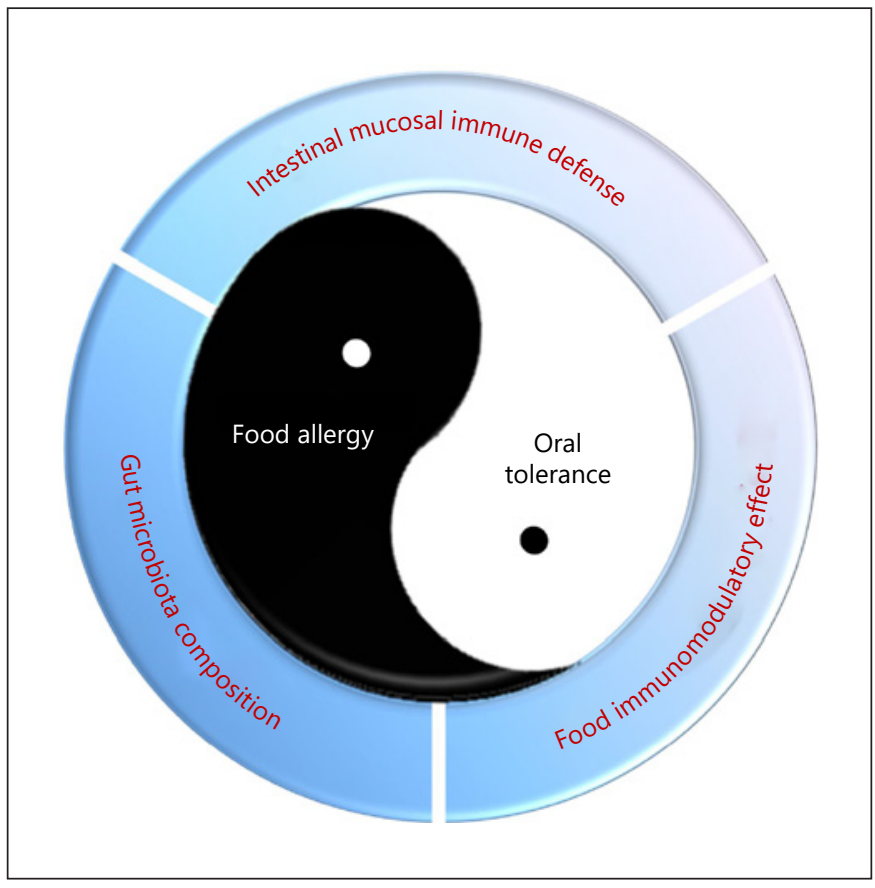

Fig. 3. An overview of the factors that contribute to oral tolerance.

sumption can accelerate tolerance to raw egg [101]. Continuous ingestion of extensively heated egg for up to 12 months was found to induce immunological changes that favor tolerance to regular egg, including smaller skin prick test wheal diameters, lower specific IgE level against OVA, and higher specific IgG4 level against both ovomucoid and OVA [102].

Milk allergy is the most common FA in children, with a prevalence of $0.5-3 \%$ among 1-year-old children in developed countries, as reviewed by Sackesen [103]. Studies have shown that $50-83 \%$ of milk allergy subjects can tolerate baked milk [104-106]. Recently, a randomized controlled trial was performed on 84 egg allergy patients who were baked milk tolerant. Results showed that, at the end of 1 year period, $88.1 \%$ of patients who consumed baked milk can tolerate unheated milk, and for those who eliminated milk from diet, the rate was 66.7\% $(p=0.018)$ [107]. The immune-modulatory effect of baked milk on milk allergy patients was also supported by other studies [108-111].

It seems that baked egg and milk are a promising oral immunotherapy for egg and milk allergy patients [113] $[112,113]$. In practice, attention should be paid to those baked milk/egg intolerant patients, since anaphylaxis may happen [114]. Moreover, matrix is also important in terms of tolerance induction [115]. However, there are 
different voices saying that baked egg/milk tolerance was due to heat-induced conformational change and that no immune-modulatory effect would be observed for the raw ingredient [116]. More data are required for baked egg/milk tolerant participants, who eliminate egg/milk from diet, to compare with baked egg/milk intolerant control or those that randomly consume or avoid baked egg/milk in order to ascertain whether tolerance rate to raw egg/milk differs.

\section{Conclusion}

The increase in FA prevalence is a direct consequence of reduced tolerance to foods. Early food introduction seems to be a useful measure for higher rate of oral tolerance induction to certain food types, but for those already annoyed by FA, oral tolerance restoration could be a choice. There are many aspects affecting oral tolerance induction and restoration, including the intestinal mucosal immune defense system, intestinal microbiota, and processing method, among others (shown in Fig 3). Baked milk and egg products showed clinical immune-modulatory effects and function as a promising oral immuno- therapy. However, although desensitization to food allergens can be induced, the rate of induced clinical tolerance is low and whether the immune response can rebound is still uncertain.

\section{Conflict of Interest Statement}

The authors have no conflicts of interest to declare.

\section{Funding Sources}

The work was supported by National Natural Science Foundation of China (Grant number 31660443); Young Talents Program of Zunyi Medical College (Grant number 18zy-009); Guizhou Province Science and Technology Projects (Grant number 20191348); and Guizhou Health and Family Planning Project (Grant number D-488).

\section{Author Contributions}

Xiaotong Yang drafted the manuscript. Rui Liang performed the format editing for submission. Qianlu Xing revised the manuscript. Xiaojuan Ma designed and coordinated the works.

\section{References}

1 Wambre E, Jeong D. Oral tolerance development and maintenance. Immunol Allergy Clin North Am. 2018 Feb;38(1):27-37.

2 Peters RL, Koplin JJ, Gurrin LC, Dharmage SC, Wake M, Ponsonby AL, et al. The prevalence of food allergy and other allergic diseases in early childhood in a population-based study: HealthNuts age 4-year follow-up. J Allergy Clin Immunol. 2017 Jul;140(1):145-e8.

3 Sasaki M, Koplin JJ, Dharmage SC, Field MJ, Sawyer SM, McWilliam V, et al. Prevalence of clinic-defined food allergy in early adolescence: the SchoolNuts study. J Allergy Clin Immunol. 2017 Jan;141(1):391-8.e4.

4 Okada Y, Yamashita T, Kumagai H, Morikawa Y, Akasawa A. Accurate determination of childhood food allergy prevalence and correction of unnecessary avoidance. Allergy Asthma Immunol Res. 2017 Jul;9(4):322-8.

5 Lyons SA, Burney PGJ, Ballmer-Weber BK, Fernandez-Rivas M, Barreales L, Clausen M, et al. Food allergy in adults: substantial variation in prevalence and causative foods across europe. J Allergy Clin Immunol Pract. 2019 Jul-Aug;7(6):1920-e11.

6 Nachshon L, Schwartz N, Elizur A, Schon Y, Cheryomukhin M, Katz Y, et al. The prevalence of food allergy in young Israeli adults. J Allergy Clin Immunol Pract. 2019 Nov-Dec; 7(8):2782-e4.
7 Botha M, Basera W, Facey-Thomas HE, Gaunt B, Gray CL, Ramjith J, et al. Rural and urban food allergy prevalence from the South African Food Allergy (SAFFA) study. J Allergy Clin Immunol. 2018 Feb;143(2):1-7.e2.

8 Gonçalves LC, Guimarães TC, Silva RM, Cheik MF, de Ramos Nápolis AC, Barbosa E Silva G, et al. Prevalence of food allergy in infants and pre-schoolers in Brazil. Allergol Immunopathol. 2016 Nov-Dec;44(6):497503.

9 Sampson HA. Food allergy: past, present and future. Allergol Int. 2016 Oct;65(4):363-9.

10 Leung ASY, Wong GWK, Tang MLK. Food allergy in the developing world. J Allergy Clin Immunol. 2018 Jan;141(1):76-e1.

11 Grabenhenrich LB, Dölle S, Moneret-Vautrin A, Köhli A, Lange L, Spindler T, et al. Anaphylaxis in children and adolescents: the European Anaphylaxis Registry. J Allergy Clin Immunol. 2016 Apr;137(4):1128-e1.

12 Turner PJ, Gowland MH, Sharma V, Ierodiakonou D, Harper N, Garcez T, et al. Increase in anaphylaxis-related hospitalizations but no increase in fatalities: an analysis of United Kingdom national anaphylaxis data, 19922012. J Allergy Clin Immunol. 2015 Apr; 135(4):956-e1.

13 Rueter K, Ta B, Bear N, Lucas M, Borland ML Prescott SL. Increased use of adrenaline in the management of childhood anaphylaxis over the last decade. J Allergy Clin Immunol Pract. 2018 Sep-Oct;6(5):1545-52.

14 Hochstadter E, Clarke A, De Schryver S, LaVieille S, Alizadehfar R, Joseph L, et al. Increasing visits for anaphylaxis and the benefits of early epinephrine administration: a 4 -year study at a pediatric emergency department in Montreal, Canada. J Allergy Clin Immunol. 2016 Jun;137(6):1888-e4.

15 Motosue MS, Bellolio MF, Van Houten HK, Shah ND, Campbell RL. National trends in emergency department visits and hospitalizations for food-induced anaphylaxis in US children. Pediatr Allergy Immunol. 2018 Aug; 29(5):538-44.

16 Jiang N, Yin J, Wen L, Li H. Characteristics of anaphylaxis in 907 Chinese patients referred to a tertiary allergy center: a retrospective study of 1952 episodes. Allergy Asthma Immunol Res. 2016 Jul;8(4):353-61.

17 Srisuwatchari W, Vichyanond P. Oral food challenges: result of a 16-year experience at a major teaching hospital in Thailand. Asia Pac allergy. 2018 Apr;8(2):e21.

18 Lee SY, Ahn K, Kim J, Jang GC, Min TK, Yang $\mathrm{HJ}$, et al. A multicenter retrospective case study of anaphylaxis triggers by age in Korean children. Allergy Asthma Immunol Res. 2016 Nov;8(6):535-40. 
19 Ebisawa M, Ito K, Fujisawa T. Japanese guidelines for food allergy 2017. Allergol Int. 2017 Apr;66(2):248-64.

20 dos Santos SC, Konstantyner T, Cocco RR. Effects of probiotics in the treatment of food hypersensitivity in children: a systematic review. Allergol Immunopath. 2020 Jan-Feb;48(1): 95-104.

21 Freeland DMH, Minogue HF, Nadeau KC. Advances in food allergy oral immunotherapy: towards tolerance. Curr Opin Immunol. 2016 Oct;42:119-23.

22 Sharquie IK, Al-Ghouleh A, Fitton P, Clark MR, Armour KL, Sewell HF, et al. An investigation into IgE-facilitated allergen recognition and presentation by human dendritic cells. BMC immunol. 2013 Dec;14(1):54.

23 Wells HG, Osborne TB. The biological reactions of the vegetable proteins I. anaphylaxis. J Infect Dis. 1911 Jan;8(1):66-124.

24 Tordesillas L, Berin MC. Mechanisms of oral tolerance. Clin Rev Allergy Immunol. 2018 Oct;55(2):107-17.

25 Rivas MN, Burton OT, Wise P, Charbonnier LM, Georgiev P, Oettgen HC, et al. Regulatory $\mathrm{T}$ cell reprogramming toward a Th2 cell like lineage impairs oral tolerance and promotes food allergy. Immunity. 2015 Mar; 42(3):512-23.

26 Burton OT, Noval Rivas M, Zhou JS, Logsdon SL, Darling AR, Koleoglou KJ, et al. Immunoglobulin E signal inhibition during allergen ingestion leads to reversal of established food allergy and induction of regulatory $\mathrm{T}$ cells. Immunity. 2014 Jul;41(1):141-51.

27 Santos AF, Brough HA. Making the most of in vitro tests to diagnose food allergy. $\mathrm{J} \mathrm{Al}-$ lergy Clin Immunol Pract. 2017 Mar-Apr; 5(2):237-48.

28 Palmer DJ, Prescott SL. Does early feeding promote development of oral tolerance? Curr Allergy Asthma Rep. 2012 Aug;12(4):321-31.

29 Du Toit G, Roberts G, Sayre PH, Bahnson HT, Radulovic S, Santos AF, et al. Randomized trial of peanut consumption in infants at risk for peanut allergy. N Engl J Med. 2015 Feb; 372(9):803-13

30 Kattan J. The prevalence and natural history of food allergy. Curr Allergy Asthma Rep. 2016 Jun;16(7):47.

31 Ruiter B, Knol EF, van Neerven RJ, Garssen J, Bruijnzeel-Koomen CA, Knulst AC, et al. Maintenance of tolerance to cow's milk in atopic individuals is characterized by high levels of specific immunoglobulin G4. Clin Exp Allergy. 2007 Jul;37(7):1103-10

32 Tan J, Mckenzie C, Vuillermin PJ, Goverse G, Vinuesa CG, Mebius RE, et al. Dietary fiber and bacterial SCFA enhance oral tolerance and protect against food allergy through diverse cellular pathways. Cell Rep. 2016 Jun; 15(12):2809-24.

33 Liu G, Hu M, Sun LC, Han X, Liu Q, Alcocer $\mathrm{M}$, et al. Allergenicity and oral tolerance of enzymatic cross-linked tropomyosin evaluated using cell and mouse models. J Agric Food Chem. 2017 Mar;65(10):2205-13.
34 Luyt D, Bravin K, Luyt J. Implementing spe cific oral tolerance induction to milk into routine clinical practice: experience from first 50 patients. J Asthma Allergy. 2014 Jan;7:1-9.

35 Dello Iacono I, Tripodi S, Calvani M, Panetta V, Verga MC, Miceli Sopo S. Specific oral tolerance induction with raw hen's egg in children with very severe egg allergy: a randomized controlled trial. Pediatr Allergy Immunol. 2013 Feb;24(1):66-74.

36 Peters RL, Dang TD, Allen KJ. Specific oral tolerance induction in childhood. Pediatr Allergy Immunol. 2016 Dec;27(8):784-94.

37 Ahluwalia B, Magnusson MK, Öhman L. Mucosal immune system of the gastrointestinal tract: maintaining balance between the good and the bad. Scand J Gastroenterol. 2017 Nov; 52(11):1185-93.

38 Tokuhara D, Kurashima Y, Kamioka M, Nakayama T, Ernst P, Kiyono H. A comprehensive understanding of the gut mucosal immune system in allergic inflammation. Allergol Int. 2019 Jan;68(1):17-25.

39 Spencer J, Macdonald TT, Finn T, Isaacson PG. The development of gut associated lymphoid tissue in the terminal ileum of fetal human intestine. Clin Exp Immunol. 1986 Jun; 64(3):536-43

40 Nagai M, Noguchi R, Takahashi D, Morikawa T, Koshida K, Komiyama S, et al. Fastingrefeeding impacts immune cell dynamics and mucosal immune responses. Cell. 2019 Aug; 178(5):1072-e14.

41 Spahn TW, Fontana A, Faria AM, Slavin AJ, Eugster HP, Zhang X, et al. Induction of oral tolerance to cellular immune responses in the absence of Peyer's patches. Eur J Immunol. 2001 Apr;31(4):1278-87.

42 Pardo-Camacho C, González-Castro AM, Rodiño-Janeiro BK, Pigrau M, Vicario M. Epithelial immunity: priming defensive responses in the intestinal mucosa. Am J Physiol Gastrointest Liver Physiol. 2017 Feb; 314(2):ajpgi-2016.

43 Wershil BK, Furuta GT. 4. Gastrointestinal mucosal immunity. J Allergy Clin Immunol, 2008 Feb;121(2 Suppl):S380-3.

44 Cheroutre H, Lambolez F, Mucida D. The light and dark sides of intestinal intraepithelial lymphocytes. Nat Rev Immunol. 2011 Jun; 11(7):445-56.

45 Kim M, Galan C, Hill AA, Wu WJ, FehlnerPeach $\mathrm{H}$, Song HW, et al. Critical role for the microbiota in CX3CR1+ intestinal mononuclear phagocyte regulation of intestinal $\mathrm{T}$ cell responses. Immunity. 2018 Jul;49(1):151-e5.

46 Antoni L, Nuding S, Wehkamp J, Stange EF. Intestinal barrier in inflammatory bowel disease. World J Gastroenterol. 2014 Feb;20(5): 1165-79.

47 Satitsuksanoa P, Jansen K, Głobińska A, van de Veen W, Akdis M. Regulatory immune mechanisms in tolerance to food allergy. Front Immunol. 2018 Dec;9:2939.

48 Uto T, Takagi H, Fukaya T, Nasu J, Fukui T, Miyanaga N, et al. Critical role of plasmacytoid dendritic cells in induction of oral toler- ance. J Allergy Clin Immunol. 2018 Jun; 141(6):2156-e9.

$49 \mathrm{Wu} \mathrm{ZQ}$. Antigen specific immunotherapy generates $\mathrm{CD} 27+\mathrm{CD} 35+$ tolerogenic dendritic cells. Cell Immunol. 2013 Jun;283(1-2): 75-80.

50 Shakhar G, Kolesnikov M. Intestinal macrophages and DCs close the gap on tolerance. Immunity. 2014 Feb;40(2):171-3.

51 Mora JR, Iwata M, Eksteen B, Song SY, Junt $\mathrm{T}$, Senman B, et al. Generation of gut-homing IgA-secreting B cells by intestinal dendritic cells. Science. 2006 Nov;314(5802):1157-60.

$52 \mathrm{Tu}$ L, Chen J, Zhang H, Duan L. Interleukin-4 inhibits regulatory $\mathrm{T}$ cell differentiation through regulating $\mathrm{CD} 103+$ dendritic cells. Front Immunol. 2017 Mar;8:214.

53 Cerovic V, Houston SA, Scott CL, Aumeunier A, Yrlid U, Mowat AM, et al. Intestinal CD103- dendritic cells migrate in lymph and prime effector $\mathrm{T}$ cells. Mucosal Immunol. 2013 Jan;6(1):104-13.

54 Shik D, Tomar S, Lee JB, Chen CY, Smith A, Wang YH. IL-9-producing cells in the development of IgE-mediated food allergy. Semin Immunopathol. 2017 Jan;39(1):69-77.

55 Berin MC, Shreffler W. T(H) 2 adjuvants: implications for food allergy. J Allergy Clin Immunol. 2008 Jun;121(6):1311-20.

56 Chiang D, Chen X, Jones SM, Wood RA, Sicherer SH, Burks AW, et al. Single-cell profiling of peanut-responsive $\mathrm{T}$ cells in patients with peanut allergy reveals heterogeneous effector TH2 subsets. J Allergy Clin Immunol. 2018 Jun;141(6):2107-20.

57 Weissler KA, Rasooly M, Dimaggio T, Bolan $\mathrm{H}$, Cantave D, Martino D, et al. Identification and analysis of peanut-specific effector $\mathrm{T}$ and regulatory $\mathrm{T}$ cells in children allergic and tolerant to peanut. J Allergy Clin Immunol. 2018 May;141(5):1699-e7.

58 Khodoun MV, Tomar S, Tocker JE, Wang YH, Finkelman FD. Prevention of food allergy development and suppression of established food allergy by neutralization of thymic stromal lymphopoietin, IL-25, and IL-33. J Allergy Clin Immunol. 2018 Jan;141(1):171-e1.

59 Breslin M, Pons L, Yue X, Kulis M, Jones SM, Vickery B, et al. Peanut oral immunotherapy (OIT) confers long-term tolerance mediated by decreased T-helper type 2 (TH2) cytokines and cytokines generated by regulatory $\mathrm{T}$ cells (Tregs). J Allergy Clin Immunol. 2010 Feb; 125(2):AB20.

60 Palomares $\mathrm{O}$. The role of regulatory $\mathrm{T}$ cells in IgE-mediated food allergy. J Investig Allergol Clin Immunol. 2013 Jan;23(6):371-82.

61 Bonnet B, Vigneron J, Levacher B, Vazquez T, Pitoiset F, Brimaud F, et al. Low-dose IL-2 induces regulatory $\mathrm{T}$ cell-mediated control of experimental food allergy. J Immunol. 2016 Jul;197(1):188-98.

62 Kim KS, Hong SW, Han D, Yi J, Jung J, Yang BG, et al. Dietary antigens limit mucosal immunity by inducing regulatory $\mathrm{T}$ cells in the small intestine. Science. 2016 Feb;351(6275): $858-63$. 
63 Dang TD, Allen KJ, J Martino D, Koplin JJ, Licciardi PV, Tang ML. Food-allergic infants have impaired regulatory T-cell responses following in vivo allergen exposure. Pediatr Allergy Immunol. $2016 \mathrm{Feb} ; 27(1): 35-43$.

64 Karlsson MR, Rugtveit J, Brandtzaeg P. Allergen-responsive $\mathrm{CD} 4+\mathrm{CD} 25+$ regulatory $\mathrm{T}$ cells in children who have outgrown cow's milk allergy. J Exp Med. 2004 Jun;199(12): 1679-88.

65 Wawrzyniak M, O'mahony L, Akdis M. Role of regulatory cells in oral tolerance. Allergy Asthma Immunol Res. 2017 Mar;9(2):10715.

66 Weiner HL. Oral tolerance: immune mechanisms and the generation of Th3-type TGFbeta-secreting regulatory cells. Microbes Infect. 2001 Sep;3(11):947-54.

67 Pérez-Machado MA, Ashwood P, Thomson MA, Latcham F, Sim R, Walker-Smith JA, et al. Reduced transforming growth factor-beta1-producing $\mathrm{T}$ cells in the duodenal mucosa of children with food allergy. Eur J Immunol. 2003 Aug;33(8):2307-15.

68 Holvoet S, Perrot M, de Groot N, Prioult G Mikogami T, Verhasselt V, et al. Oral tolerance induction to newly introduced allergen is favored by a transforming growth factor- $\beta$ enriched formula. Nutrients. 2019 Sep;11(9): 2210.

69 Carrier Y, Yuan J, Kuchroo VK, Weiner HL. Th3 cells in peripheral tolerance. I. Induction of Foxp3-positive regulatory $\mathrm{T}$ cells by $\mathrm{Th} 3$ cells derived from TGF- $\beta$ T cell-transgenic mice. J Immunol. 2007 Jan;178(1):179-85.

70 Penttila IA. Milk-derived transforming growth factor-beta and the infant immune response. J Pediatr. 2010 Feb;156(2 Suppl):S215 .

71 Khaleva E, Gridneva Z, Geddes DT, Oddy $\mathrm{WH}$, Colicino S, Blyuss O, et al. Transforming growth factor beta in human milk and allergic outcomes in children: a systematic review. Clin Exp Allergy. 2019 Sep;49(9):1201-13.

72 Groux H, O'Garra A, Bigler M, Rouleau M Antonenko S, de Vries JE, et al. A CD4+ T-cell subset inhibits antigen-specific T-cell responses and prevents colitis. Nature. 1997 Oct;389(6652):737-42.

73 Tsuji NM, Mizumachi K, Kurisaki J. Interleukin-10-secreting Peyer's patch cells are responsible for active suppression in low-dose oral tolerance. Immunology. 2001 Aug; 103(4):458-64

74 Bergerson JR, Erickson K, Singh AM. Tr1 cell identification and phenotype in children with and without food allergy. J Allergy Clin Immunol. 2017 Feb;139(2):AB70.

75 Tiemessen MM, Van Ieperen-Van Dijk AG, Bruijnzeel-Koomen CA, Garssen J, Knol EF, Van Hoffen E. Cow's milk-specific T-cell reactivity of children with and without persistent cow's milk allergy: key role for IL-10. J Allergy Clin Immunol. 2004 May;113(5): 932-9.

76 Oft M. Immune regulation and cytotoxic $\mathrm{T}$ cell activation of IL-10 agonists - Preclinical and clinical experience. Semin Immunol. 2019 Aug;44:101325.

77 Clarke K, Chintanaboina J. Allergic and immunologic perspectives of inflammatory bowel disease. Clin Rev Allergy Immunol. 2019 Oct;57(2):179-93.

78 Hartono S, Ippoliti MR, Mastroianni M, Torres R, Rider NL. Gastrointestinal disorders associated with primary immunodeficiency diseases. Clin Rev Allergy Immunol. 2019 Oct; 57(2):145-65.

79 Chen B, Sun L, Zhang X. Integration of microbiome and epigenome to decipher the pathogenesis of autoimmune diseases. J Autoimmun. 2017 Sep;83:31-42

80 Wang HG, Liu SP, Ma TH, Yan W, Zhou JF, Shi YT, et al. Fecal microbiota transplantation treatment for refractory ulcerative colitis with allergy to 5-aminosalicylic acid: a case report. Medicine. 2018 May;97(19):e0675.

81 Dzidic M, Abrahamsson TR, Artacho A, Collado MC, Mira A, Jenmalm MC. Oral microbiota maturation during the first 7 years of life in relation to allergy development. Allergy. 2018 Oct;73(10):2000-11.

82 Ho H-E, Bunyavanich S. Role of the microbiome in food allergy. Curr Allergy Asthma Rep. 2018 Apr;18(4):27.

83 Rodriguez B, Prioult G, Bibiloni R, Nicolis I, Mercenier A, Butel MJ, et al. Germ-free status and altered caecal subdominant microbiota are associated with a high susceptibility to cow's milk allergy in mice. FEMS Microbiol Ecol. 2011 Apr;76(1):133-44.

84 Rodriguez B, Prioult G, Hacini-Rachinel F, Moine D, Bruttin A, Ngom-Bru C, et al. Infant gut microbiota is protective against cow's milk allergy in mice despite immature ileal Tcell response. FEMS Microbiol Ecol. 2012 Jan; 79(1):192-202.

85 Rautava S, Luoto R, Salminen S, Isolauri E. Microbial contact during pregnancy, intestinal colonization and human disease. Nat Rev Gastroenterol Hepatol. 2012 Oct;9(10):56576.

86 Pannaraj PS, Li F, Cerini C, Bender JM, Yang $\mathrm{S}$, Rollie A, et al. Association between breast milk bacterial communities and establishment and development of the infant gut microbiome. JAMA Pediatr. 2017 Jul;171(7): 647-54.

87 Azad MB, Konya T, Guttman DS, Field CJ, Sears MR, HayGlass KT, et al. Infant gut microbiota and food sensitization: associations in the first year of life. Clin Exp Allergy. 2015; 45(3):632-43.

88 Abrams EM, Greenhawt M, Fleischer DM, Chan ES. Early solid food introduction: role in food allergy prevention and implications for breastfeeding. J Pediatr. 2017 May; 184: $13-8$.

89 Burgess JA, Dharmage SC, Allen K, Koplin J, Garcia-Larsen V, Boyle R, et al. Age at introduction to complementary solid food and food allergy and sensitization: a systematic review and meta-analysis. Clin Exp Allergy. 2019 Jun;49(6):754-69.
90 Soriano VX, Peters RL, Ponsonby AL, Dharmage SC, Perrett KP, Field MJ, et al. Earlier ingestion of peanut after changes to infant feeding guidelines: the EarlyNuts study. J Allergy Clin Immunol. 2019 Nov; 144(5): 1327-e5.

91 Greenhawt M. The national institutes of allergy and infectious diseases sponsored guidelines on preventing peanut allergy: a new paradigm in food allergy prevention. Allergy Asthma Proc. 2017 Mar;38(2):92-

92 Gao X, Yan Y, Zeng G, Sha T, Liu S, He Q, et al. Influence of prenatal and early-life exposures on food allergy and eczema in infancy: a birth cohort study. BMC Pediatr. 2019 Jul; 19(1):239.

93 Monaco S, Russo G, Romano A, Liotti L, Verga MC, Miceli Sopo S. Yogurt is tolerated by the majority of children with IgE-mediated cow's milk allergy. Allergol Immunopathol. 2019 Jul-Aug;47(4):322-7.

94 Küçükosmanoğlu E, Özen E, Eltan SB, Özkars MY, Keskin O. Most children who are allergic to cow's milk tolerate yogurt. J Int Med Res. 2018 Dec;46(12):5099-106.

95 El-Qutob D. Shrimp allergy: beyond avoidance diet. Eur Ann Allergy Clin Immunol. 2017 Nov;49(6):252-6.

96 Upton J, Nowak-Wegrzyn A. The impact of baked egg and baked milk diets on IgE- and non-IgE-mediated allergy. Clin Rev Allergy Immunol. 2018 Oct;55(2):118-38.

97 Saifi M, Swamy N, Crain M, Brown LS, Bird JA. Tolerance of a high-protein baked-egg product in egg-allergic children. Ann Allergy Asthma Immunol. 2016 May;116(5):415-

98 Sopo SM, Greco M, Cuomo B, Bianchi A, Liotti L, Monaco S, et al. Matrix effect on baked egg tolerance in children with IgEmediated hen's egg allergy. Pediatr Allergy Immunol. 2016 Aug;27(5):465-70.

99 Capucilli P, Cianferoni A, Fiedler J, Gober L, Pawlowski N, Ram G, et al. Differences in egg and milk food challenge outcomes based on tolerance to the baked form. Ann Allergy Asthma Immunol. 2018 Nov;121(5):580-7.

100 Leonard SA, Sampson HA, Sicherer SH, Noone S, Moshier EL, Godbold J, et al. Dietary baked egg accelerates resolution of egg allergy in children. J Allergy Clin Immunol. 2012 Aug;130(2):473-e1.

101 Pérez-Quintero O, Martinez-Azcona O, Balboa V, Vila L. Daily baked egg intake may accelerate the development of tolerance to raw egg in egg-allergic children. Eur J Pediatr. 2020 Apr;179(4):679-82.

102 Lemon-Mulé H, Sampson HA, Sicherer SH Shreffler WG, Noone S, Nowak-Wegrzyn A. Immunologic changes in children with egg allergy ingesting extensively heated egg. J Allergy Clin Immunol. 2008 Nov; 122(5):977e1.

103 Sackesen C. Epidemiology of cow's milk allergy: has it changed? Clin Transl Allergy. 2011 Aug;1(S1):S50. 
104 Leonard SA, Nowak-Węgrzyn AH. Baked milk and egg diets for milk and egg allergy management. Immunol Allergy Clin North Am. 2016 Feb;36(1):147-59.

105 Uncuoglu A, Yologlu N, Simsek IE, Uyan ZS, Aydogan M. Tolerance to baked and fermented cow's milk in children with IgE-mediated and non-IgE-mediated cow's milk allergy in patients under two years of age. Allergol Immunopathol. 2017 Nov-Dec;45(6): 560-6.

106 Barbosa CPG, Gushken AAKF, Yonamine GH, Castro APBM, Pastorino AC, Jacob CMA. Tolerance to baked milk in Brazilian children with persistent cow's milk allergy. Clin Transl Allergy. 2015 Mar;5(3):S165.

107 Esmaeilzadeh H, Alyasin S, Haghighat M, Nabavizadeh H, Esmaeilzadeh E, Mosavat F. The effect of baked milk on accelerating unheated cow's milk tolerance: a control randomized clinical trial. Pediatr Allergy Immunol. 2018 Nov;29(7):747-53.

108 Nowak-Węgrzyn A, Lawson K, Masilamani M, Kattan J, Bahnson HT, Sampson HA. Increased tolerance to less extensively heat-denatured (baked) milk products in milk-allergic children. J Allergy Clin Immunol Pract. 2018 Mar-Apr;6(2):486-e5.

109 Leonard SA. Debates in allergy medicine: baked milk and egg ingestion accelerates resolution of milk and egg allergy. World Allergy Organ J. 2016 Jan;9:1.

110 Luyt D, Ball H, Makwana N, Green MR, Bravin K, Nasser SM, et al. BSACI guideline for the diagnosis and management of cow's milk allergy. Clin Exp Allergy. 2014 Mar; 44(5):642-72.

111 Andrews T, Banks JR. Dietary baked milk accelerates the resolution of cow's milk allergy in children. Pediatrics. 2012 Oct; 130(1):S13.

112 Leonard SA. Baked egg and milk exposure as immunotherapy in food allergy. Curr Allergy Asthma Rep. 2016 Apr;16(4):32.

113 Konstantinou GN. Safety and efficacy balance of baked milk and egg oral immunotherapy. Curr Treat Options Allergy. 2017 Aug;4(3):370-82.
114 Goldberg MR, Nachshon L, Appel MY, Elizur A, Levy MB, Eisenberg E, et al. Efficacy of baked milk oral immunotherapy in baked milk-reactive allergic patients. J Allergy Clin Immunol. 2015 Dec;136(6):1601-6.

115 Sopo SM, Greco M, Monaco S, Bianchi A, Cuomo B, Liotti L, et al. Matrix effect on baked milk tolerance in children with IgE cow milk allergy. Allergol Immunopath. 2016 Nov-Dec;44(6):517-23.

116 Lambert R, Grimshaw KEC, Ellis B, Jaitly J, Roberts G. Evidence that eating baked egg or milk influences egg or milk allergy resolution: a systematic review. Clin Exp Allergy. 2017 Jun;47(6):829-37.

117 Des Roches A, Nguyen M, Paradis L, Primeau MN, Singer S. Tolerance to cooked egg in an egg allergic population. Allergy. $2006 \mathrm{Jul}$; 61(7):900-1.

118 Ballmer-Weber BK, Brockow K, Fiocchi A, Theler B, Vogel L, Ring J, et al. Hydrolysed egg displays strong decrease in allergenicity and is well tolerated by egg-allergic patients. Allergy. 2016 May; 71(5):728-32.

119 Bartnikas LM, Sheehan WJ, Larabee KS, Petty C, Schneider LC, Phipatanakul W. Ovomucoid is not superior to egg white testing in predicting tolerance to baked egg. J Allergy Clin Immunol Pract. 2013 Jul-Aug; 1(4):354-60.

120 Turner PJ, Mehr S, Joshi P, Tan J, Wong M, Kakakios A, et al. Safety of food challenges to extensively heated egg in egg-allergic children: a prospective cohort study. Pediatr Allergy Immunol. 2013 Aug;24(5):450-5.

121 Buelow BJ, Lee C, Zafra HT, Dasgupta M, Hoffmann RG, Vasudev M. Egg baked in product open oral food challenges are safe in selected egg-allergic patients. Allergy Rhinol. 2014 Jul;5(2):110-2.

122 Cortot CF, Sheehan WJ, Permaul P, Friedlander JL, Baxi SN, Gaffin JM, et al. Role of specific IgE and skin-prick testing in predicting food challenge results to baked egg. Allergy Asthma Proc. 2012 May-Jun;33(3): 275-81.

123 Lieberman JA, Huang FR, Sampson HA, Nowak-Węgrzyn A. Outcomes of 100 con- secutive open, baked-egg oral food challenges in the allergy office. J Allergy Clin Immunol. 2012 Jun;129(6):1682-e2.

124 Miceli Sopo S, Romano A, Bersani G, Fantacci C, Badina L, Longo G, et al. Cooking influence in tolerance acquisition in egginduced acute food protein enterocolitis syndrome. Allergol Immunopathol. 2019 May-Jun;47(3):221-6.

125 Sirin Kose S, Asilsoy S, Uzuner N, Karaman $\mathrm{O}$, Anal O. Outcomes of baked milk and egg challenge in cow's milk and hen's egg allergy: can tolerance be predicted with allergenspecific IgE and prick-to-prick test? Int Arch Allergy Immunol. 2019 Oct;180(4):264-73.

126 Kim JS, Nowak-Węgrzyn A, Sicherer SH, Noone S, Moshier EL, Sampson HA. Dietary baked milk accelerates the resolution of cow's milk allergy in children. J Allergy Clin Immunol. 2011 Jul;128(1):125-e2.

127 Bartnikas LM, Sheehan WJ, Hoffman EB, Permaul P, Dioun AF, Friedlander J, et al. Predicting food challenge outcomes for baked milk: role of specific $\operatorname{IgE}$ and skin prick testing. Ann Allergy Asthma Immunol. 2012 Nov; 109(5):309-e1.

128 Mehr S, Turner PJ, Joshi P, Wong M, Campbell DE. Safety and clinical predictors of reacting to extensively heated cow's milk challenge in cow's milk-allergic children. Ann Allergy Asthma Immunol. 2014 Oct;113(4): 425-9.

129 Gruzelle V, Juchet A, Martin-Blondel A, Michelet M, Chabbert-Broue A, Didier A. Benefits of baked milk oral immunotherapy in French children with cow's milk allergy. Pediatr Allergy Immunol. 2020 May;31(4): 364-70.

130 Stavroulakis G, Giavi S, Douladiris N, Manousakis M, Papadopoulos NG. Fish allergynatural history and crossreactivity between fish species. Clin Transl Allergy. $2011 \mathrm{Feb}$ 1(S1):O26.

131 Bernhisel-Broadbent J, Strause D, Sampson HA. Fish hypersensitivity. II: clinical relevance of altered fish allergenicity caused by various preparation methods. J Allergy Clin Immunol. 1992 Oct;90(4 Pt 1):622-9. 